\title{
On the occasion of the 80th birthday of Dr Naranjan S Dhalla
}

\author{
Grant N Pierce PhD FACC FAHA FAPS FIACS FISHR FCAHS FRSM (London) FRSC
}

$\mathrm{N}$

aranjan S Dhalla was born in 1936 in the Punjab region of India. Although most may assume he emigrated to Canada shortly after his undergraduate studies in India, the reality is that he was trained and began his scientific career in the United States. NS Dhalla obtained his MSc degree from the University of Pennsylvania (Philadelphia, USA) in 1963 and completed his $\mathrm{PhD}$ two years later at the University of Pittsburgh (Pittsburgh, USA). His first faculty position was also not in Canada but at St Louis University (St Louis, Missouri, USA) as an assistant professor before he was lured by the Department of Physiology Chair at the time, Dr Arnold Naimark, to come to Winnipeg, Manitoba, and begin his academic career at the University of Manitoba. He would stay at the University of Manitoba for the rest of his distinguished scientific career, now nearly 50 years.

Dr Dhalla became renowned in the 1970s for his discoveries of the subcellular basis of cardiac pathophysiology. His works, describing in detail the many defects in sarcolemmal, sarcoplasmic reticular, mitochondrial and myofibrillar dysfunction and their association with cardiac contractile dysfunction, resulted in his world prominence in cardiovascular science. This research focus has formed the basis for the nearly 800 full-length articles that he has published during his career. He has edited or authored 52 books in the area of heart research. He has trained 163 fellows and students who are performing independent research around the globe. He has been invited to speak at 500 national and international conferences as well as academic institutions. For the past 29 years, he has been the Editor-in-Chief of the international journal Molecular and Cellular Biochemistry.

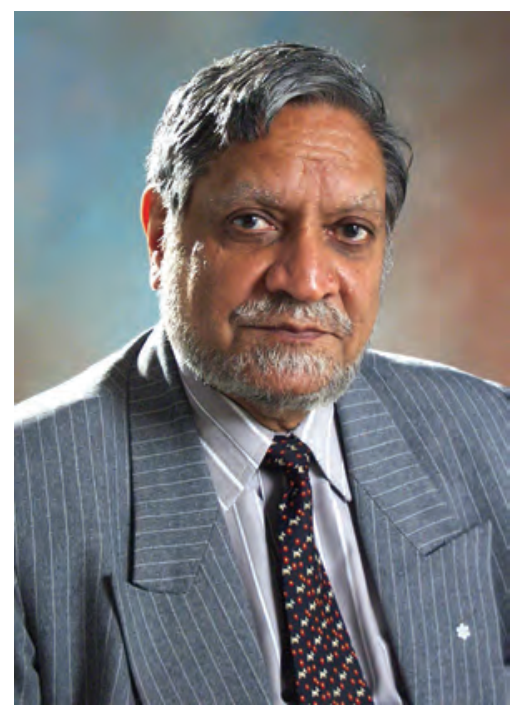

His career has been nothing short of prolific. However, what separates Dr Dhalla from other famous cardiovascular scientists of his time is his additional contributions to the development of global scientific organizations focused on cardiovascular function and disease. Dr Dhalla played a critical role for decades as first, the Secretary General of the International Society of Heart Research (ISHR) and then later as its Vice President, President and Past President. His dedication and energetic work were directly responsible for the creation of the ISHR as a world recognized cardiovascular research organization, and it is largely due to his efforts that it exists to this day. He then created the International Academy of Cardiovascular Sciences in 1996 for the promotion of young investigators in this area, and the education of cardiovascular scientists and the public all over the world. His work has been recognized with many honorary degrees and professorships from institutions all over the globe. He has received 186 honours and awards from many countries including the Order of Canada, Order of Manitoba, Fellowship in the Royal Society of Canada, the Medal of Honour of the Canadian Medical Association, and the Research Achievement Award of the Canadian Cardiovascular Society, to name just a few. His bust has been installed in the Citizens Hall of Fame in Winnipeg.

On the occasion of the 80th birthday of Dr Naranjan S. Dhalla, it is not only cause to light a few birthday candles on a very large cake, it is time to celebrate a man, a scientist and a dedicated academician who has sacrificed much to the benefit of so many. Happy 80th birthday Professor!

Cell Biology Laboratory, Institute of Cardiovascular Sciences, Department of Physiology, University of Manitoba, Winnipeg, Manitoba Correspondence: Dr Grant N Pierce, University of Manitoba, Winnipeg, Manitoba. E-mail gpierce@sbrc.ca 